\title{
Bacteriological Quality of Abattoir Effluents Discharged into Water Bodies in Abuja, Nigeria
}

\author{
W. D. Nafarnda, ${ }^{1}$ I. E. Ajayi, ${ }^{2}$ J. C. Shawulu, ${ }^{2}$ M. S. Kawe, ${ }^{3}$ G. K. Omeiza, ${ }^{1}$ N. A. Sani, ${ }^{4}$ \\ O. Z. Tenuche, ${ }^{4}$ D. D. Dantong, ${ }^{2}$ and S. Z. Tags ${ }^{2}$ \\ ${ }^{1}$ Department of Veterinary Public Health and Preventive Medicine, Faculty of Veterinary Medicine, University of Abuja, \\ PMB 117, Abuja 901001, Nigeria \\ ${ }^{2}$ Department of Veterinary Anatomy, Faculty of Veterinary Medicine, University of Abuja, PMB 117, Abuja 901001, Nigeria \\ ${ }^{3}$ Department of Veterinary Parasitology and Entomology, Faculty of Veterinary Medicine, University of Abuja, PMB 117, \\ Abuja 901001, Nigeria \\ ${ }^{4}$ Department of Veterinary Pathology, Faculty of Veterinary Medicine, University of Abuja, PMB 117, Abuja 901001, Nigeria
}

Correspondence should be addressed to W. D. Nafarnda, nafarnda@yahoo.com

Received 28 March 2012; Accepted 3 June 2012

Academic Editors: A. Balkema-Buschmann, P. Butaye, and M. H. Kogut

Copyright ( 92012 W. D. Nafarnda et al. This is an open access article distributed under the Creative Commons Attribution License, which permits unrestricted use, distribution, and reproduction in any medium, provided the original work is properly cited.

\begin{abstract}
Bacteriological characteristics of abattoir effluents (wastewater), abattoir water source, and water bodies receiving abattoir wastewater were investigated in Abuja, Nigeria using the multiple-tube fermentation technique. Source of water to the abattoirs and the usage of water bodies receiving abattoir effluents were determined using questionnaires. Bacterial counts ranged from $4.8 \times 10^{6}$ to $5.8 \times 10^{5} / 100 \mathrm{~mL}$ of total coliform (TC), $8.2 \times 10^{4}$ to $3.2 \times 10^{4} / 100 \mathrm{~mL}$ of Fecal coliform $(\mathrm{FC}), 5.2 \times 10^{4}$ to $2.0 \times$ $10^{4} / 100 \mathrm{~mL}$ of Fecal streptococcus and $1.2 \times 10^{4}$ to $2.0 \times 10^{3} / 100 \mathrm{~mL}$ of Escherichia coli for abattoir effluents $6.6 \times 10^{5}$ to $6.0 \times$ $10^{5} / 100 \mathrm{~mL}$ of TC, $6.2 \times 10^{4}$ to $1.8 \times 10^{4} / 100 \mathrm{~mL}$ of FC, $1.8 \times 10^{4}$ to $6.0 \times 10^{3} / 100 \mathrm{~mL}$ of $\mathrm{F}$. streptococcus, and $4.8 \times 10^{3}$ to 6.6 $\times 10^{2} / 100 \mathrm{~mL}$ of $E$. coli for water bodies receiving abattoir effluents $100 \mathrm{~m}$ downstream. TC bacteria counts for abattoir effluents exceeded recommended limit for discharge into surface water in Nigeria. No significant difference $(P<0.05)$ was observed between bacterial counts of abattoir effluents and receiving water bodies $100 \mathrm{~m}$ downstream: an indication of contamination of receiving water bodies by abattoir effluents and possible public and environmental health hazards.
\end{abstract}

\section{Introduction}

In Nigeria, the abattoir industry is an important component of the livestock industry providing domestic meat supply to over 150 million people and employment opportunities for teaming population. However, the abattoir industries are less developed in developing countries like Nigeria. Facilities for the treatment of abattoir effluents are lacking, unlike in developed countries where these facilities are adequately provided [1]. Potential health risks from waterborne pathogens can exist in water contaminated by abattoir effluents [2], runoff from feedlots [3], dairy farms [4], grazed pastures [5, 6], fallow and sod amended with poultry litter [7], grassland treated with dairy manure [8], and sewage sludge treated land [9]. Such contamination of water bodies from abattoir wastes could constitute significant environmental and public health hazards [10-13].

Bacteria from abattoir waste discharged into water columns can subsequently be absorb to sediments, and when the bottom stream is disturbed, the sediment releases the bacteria back into the water columns presenting longterm health hazards [14]. Pathogens present in animal carcasses or shed in animal wastes may include rotaviruses, hepatitis E virus, Salmonella spp., E. coli O157: H7, Yersinia enterocolitica, Campylobacter spp., Cryptosporidium parvum, and Giardia lamblia [15]. The primary reservoir for E. coli $\mathrm{O} 157: \mathrm{H} 7$ has been reported to be healthy cattle in a study in Canada, although this bacterium is also endemic to swine and sheep [16]. These zoonotic pathogen can exceed millions to billions per gram of feces, and may infect humans 
through various routes such as contaminated air, contact with livestock animals or their waste products, swimming in water impacted by animal feces, exposure to potential vectors (such as flies, mosquitoes, water fowl, and rodents), or consumption of food or water contaminated by animal wastes $[17,18]$. The consequences of infection by pathogens originating from animal wastes can range from temporary morbidity to mortality, especially in high-risk individuals. Due to the difficulties in quantifying pathogens, indicators of fecal pollution, including coliform bacteria, fecal coliforms, E. coli, and/or Enterococci have been monitored in lieu of overt pathogens for more than 100 years [19]. Epidemiological evidence supports the relationship between the fecal indicator bacteria E. coli, Enterococci, and the incidence of gastrointestinal illness following recreational water exposure and provides the basis for water quality regulations [20].

In Nigeria, abattoir wastes are sources of embarrassment that requires immediate remedy [21]. Abattoir wastes with large quantities of animal faeces are often channeled directly into water bodies, used for domestic purposes by human beings. In Port Harcourt area of Nigeria, abattoir effluents are channeled directly without treatment into one of the tributaries of the river Niger [22].

The bacteriological characteristics of abattoir wastewater and its possible effect on receiving water bodies which is likely to cause pollution with intensified environmental and public health hazards has not been documented in Abuja, Nigeria. The objective of this study was therefore, to investigate the bacteriological characteristics of abattoir wastewater, to determine its strength, its relationship with receiving water bodies and possible public/environmental health hazards in Abuja, Nigeria. The results are based on mean concentrations of total colifrom (TC), fecal coliform (FC), Fecal streptococcus, and Escherichia coli in samples of abattoir wastewater, water servicing the abattoirs, and receiving water bodies collected at 5 major abattoirs in Abuja. Data on the usage of receiving water bodies and sources of water servicing the abattoirs were also obtained. Results obtained could be helpful in defining future abattoir wastewater treatment and management practices in Nigeria and elsewhere.

\section{Methods and Materials}

Samples and data were collected from five major abattoirs in Abuja and water bodies receiving abattoir wastewater. Abuja is the federal capital of Nigeria with a population of about 1.857 million people and one of the fastest growing cities in the world [23]. It is located in the north central part of Nigeria, with coordinates of $9^{\circ} 4^{\prime} 0^{\prime \prime} \mathrm{N} 7^{\circ} 29^{\prime} 0^{\prime \prime} \mathrm{E}$ and a total land area of $713 \mathrm{~km}^{2}(275.3 \mathrm{sq} \mathrm{m})$. The 5 major abattoirs serving the city and its environs are the Deidei, Gwagwalada, Karu, Kubwa, and Kuje abattoirs. Animals slaughtered at the 5 major abattoirs include cattle, sheep, and goats, with average daily slaughter figures of 350 cattle, 450 sheep, and 670 goats.

2.1. Sample Collection and Analyses. Samples were collected from Deidei, Gwagwalada, Karu, Kubwa, and Kuje abattoirs between the months of January and August 2011. The abattoirs were visited at 4 days interval (every market day of the area) to collect samples. A total of 60 samples were collected from each of the abattoirs during the period. Samples were collected in the morning during the peak activities between 08.00 am and 09.00 am using the grab sampling method with a wide mouthed $500 \mathrm{~mL}$ sterilized Pyrex glass bottles with tight screw dust proof stoppers. Wastewater samples were collected at the abattoirs from a point where it is thoroughly mixed and close to the discharging point (outlet) $100 \mathrm{~mm}$ below the surface, samples from receiving water bodies were collected $100 \mathrm{~m}$ upstream and downstream (before and after mixing with the abattoir wastewater), respectively. The distance was determined using a meter measuring tape. The bottles were filled leaving a top space of about $2.5 \mathrm{~cm}$. Samples were stored on ice for transportation to the laboratory and between separation procedures. Samples were processed and incubated within 5 hours of sampling. Extracts from these samples were first diluted in peptone water $0 \cdot 1 \% ; 10 \mathrm{~mL}$ of the sample were added to $90 \mathrm{~mL}$ of the diluents, producing a dilution of $10^{-1}$. Successive decimal dilutions were obtained, and then prepared for the analyses of TC, FC, E. coli, and F. streptococcus using the multiple-tube most probable number (MPN) fermentation technique. The presumptive, confirmed and completed tests were carried out as described in the Standard Methods for the Examination of Water and Wastewater, American Public Health Association [24]. The numbers of positive findings were enumerated and statistical tables (MPN tables) were used to determine bacteria counts.

A well structured questionnaire was orally administered to obtain data on the water servicing the abattoirs and the usage of water bodies receiving abattoir wastewater. The distance from abattoir wastewater outlet to water bodies and the point of usage of the receiving water bodies were measured using a meter measuring tape at each abattoir. Information on abattoir wastewater treatment methods before discharging was obtained using a questionnaire.

The mean value concentrations of TC, FC, F. streptococcus, and E. coli (MPN/100 mL) for abattoir wastewater, water servicing the abattoirs, and water bodies receiving abattoir wastewater were determined. Microbial concentrations of the abattoir wastewater, water servicing the abattoirs, upstream and downstream water bodies receiving abattoir wastewater were compared $(P<0.05)$ to establish if there is any relationship. The TC counts of the abattoir wastewater were also compared with the Federal Environmental Protection Agency (FEPA) [25] recommended level for the discharge of industrial wastewater into surface water and land application in Nigeria.

\section{Results}

Water servicing the abattoirs were from borehole, well and stream water at Deidei, Karu, and Kuje abattoirs while borehole and well water were used at Gwagwalada and Kubwa abattoirs. Untreated abattoir wastewater was discharged directly into water bodies (streams, rivers, and 
TABLE 1: Bacteriological characteristics of Deidei abattoir wastewater, source of water used at the abattoir, receiving water bodies upstream and downstream, TC effluents limit for discharge into water bodies and land application in Nigeria (MPN/100 mL).

\begin{tabular}{lcccccc}
\hline Parameter & $\begin{array}{c}\text { Mean value of } \\
\text { abattoir wastewater }\end{array}$ & $\begin{array}{c}\text { Mean value of } \\
\text { water used at } \\
\text { the abattoir }\end{array}$ & $\begin{array}{c}\text { Mean value } \\
\text { of water body } \\
\text { upstream }\end{array}$ & $\begin{array}{c}\text { Mean value } \\
\text { of water body } \\
\text { downstream }\end{array}$ & $\begin{array}{c}\text { *Effluent limit for } \\
\text { discharge into surface } \\
\text { water in Nigeria }\end{array}$ & $\begin{array}{c}* \text { Effluent limit for } \\
\text { discharge into land } \\
\text { application in Nigeria }\end{array}$ \\
\hline TC & $3.2 \times 10^{6}$ & $2.2 \times 10^{3}$ & $6.2 \times 10^{3}$ & $6.6 \times 10^{5}$ & $4.0 \times 10^{2}$ & $5.0 \times 10^{2}$ \\
FC & $6.2 \times 10^{4}$ & $2.8 \times 10^{2}$ & $2.6 \times 10^{3}$ & $3.4 \times 10^{4}$ & - & - \\
F. streptococcus & $2.1 \times 10^{4}$ & $4.5 \times 10$ & $1.2 \times 10^{2}$ & $1.0 \times 10^{4}$ & - \\
E. coli & $3.2 \times 10^{3}$ & $2.8 \times 10$ & $1.0 \times 10^{2}$ & $2.1 \times 10^{3}$ & - \\
\hline
\end{tabular}

TABLE 2: Bacteriological characteristics of Gwagwalada abattoir wastewater, source of water used at the abattoir, receiving water bodies upstream and downstream, TC effluents limit for discharge into water bodies and land application in Nigeria (MPN/100 mL).

\begin{tabular}{lcccccc}
\hline Parameter & $\begin{array}{c}\text { Mean value of } \\
\text { abattoir wastewater }\end{array}$ & $\begin{array}{c}\text { Mean value of } \\
\text { water used at } \\
\text { the abattoir }\end{array}$ & $\begin{array}{c}\text { Mean value } \\
\text { of water body } \\
\text { upstream }\end{array}$ & $\begin{array}{c}\text { Mean value } \\
\text { of water body } \\
\text { downstream }\end{array}$ & $\begin{array}{c}\text { *Effluent limit for } \\
\text { discharge into surface } \\
\text { water in Nigeria }\end{array}$ & $\begin{array}{c}* \text { Effluent limit for } \\
\text { discharge into land } \\
\text { application in Nigeria }\end{array}$ \\
\hline TC & $8.2 \times 10^{5}$ & $1.2 \times 10^{2}$ & $1.4 \times 10^{3}$ & $6.2 \times 10^{5}$ & $4.0 \times 10^{2}$ & $-5.0 \times 10^{2}$ \\
FC & $4.4 \times 10^{4}$ & $2.6 \times 10$ & $2.2 \times 10^{2}$ & $3.4 \times 10^{4}$ & - \\
F. streptococcus & $2.0 \times 10^{4}$ & $2.1 \times 10$ & $2.1 \times 10^{2}$ & $6.0 \times 10^{3}$ & - \\
E. coli & $2.0 \times 10^{3}$ & $1.2 \times 10$ & $4.4 \times 10$ & $6.6 \times 10^{2}$ & - \\
\hline
\end{tabular}

TABLE 3: Bacteriological characteristics of Karu abattoir wastewater, source of water used at the abattoir, receiving water bodies upstream and downstream, TC effluents limit for discharge into water bodies and land application in Nigeria (MPN/100 mL).

\begin{tabular}{lcccccc}
\hline Parameter & $\begin{array}{c}\text { Mean value of } \\
\text { abattoir wastewater }\end{array}$ & $\begin{array}{c}\text { Mean value of } \\
\text { water used at } \\
\text { the abattoir }\end{array}$ & $\begin{array}{c}\text { Mean value } \\
\text { of water body } \\
\text { upstream }\end{array}$ & $\begin{array}{c}\text { Mean value } \\
\text { of water body } \\
\text { downstream }\end{array}$ & $\begin{array}{c}\text { *Effluent limit for } \\
\text { discharge into surface } \\
\text { water in Nigeria }\end{array}$ & $\begin{array}{c}\text { *Effluent limit for } \\
\text { discharge into land } \\
\text { application in Nigeria }\end{array}$ \\
\hline TC & $4.8 \times 10^{6}$ & $2.0 \times 10^{3}$ & $5.2 \times 10^{3}$ & $6.6 \times 10^{5}$ & $4.0 \times 10^{2}$ & - \\
FC & $8.2 \times 10^{4}$ & $1.6 \times 10^{2}$ & $3.4 \times 10^{2}$ & $6.2 \times 10^{4}$ & - & - \\
F. streptococcus & $5.2 \times 10^{4}$ & $1.0 \times 10^{2}$ & $1.2 \times 10^{2}$ & $1.8 \times 10^{4}$ & - \\
E. coli & $1.2 \times 10^{4}$ & $2.8 \times 10$ & $2.0 \times 10^{2}$ & $4.8 \times 10^{3}$ & - \\
\hline
\end{tabular}

TABLE 4: Bacteriological characteristics of Kubwa abattoir wastewater, source of water used at the abattoir, receiving water bodies upstream and downstream, TC effluents limit for discharge into water bodies and land application in Nigeria (MPN/100 mL).

\begin{tabular}{lcccccc}
\hline Parameter & $\begin{array}{c}\text { Mean value of } \\
\text { abattoir wastewater }\end{array}$ & $\begin{array}{c}\text { Mean value of } \\
\text { water used at } \\
\text { the abattoir }\end{array}$ & $\begin{array}{c}\text { Mean value } \\
\text { of water body } \\
\text { upstream }\end{array}$ & $\begin{array}{c}\text { Mean value } \\
\text { of water body } \\
\text { downstream }\end{array}$ & $\begin{array}{c}\text { *Effluent limit for } \\
\text { discharge into surface } \\
\text { water in Nigeria }\end{array}$ & $\begin{array}{c}* \text { Effluent limit for } \\
\text { discharge into land } \\
\text { application in Nigeria }\end{array}$ \\
\hline TC & $3.2 \times 10^{6}$ & $2.0 \times 10^{2}$ & $2.6 \times 10^{3}$ & $6.1 \times 10^{5}$ & $4.0 \times 10^{2}$ & $-1.0 \times 10^{2}$ \\
FC & $3.2 \times 10^{4}$ & $1.0 \times 10^{2}$ & $3.8 \times 10^{2}$ & $1.8 \times 10^{4}$ & - \\
F. streptococcus & $3.1 \times 10^{4}$ & $2.4 \times 10$ & $2.0 \times 10^{2}$ & $1.4 \times 10^{4}$ & - \\
E. coli & $5.4 \times 10^{3}$ & $2.0 \times 10$ & $1.0 \times 10^{2}$ & $3.0 \times 10^{3}$ & - \\
\hline
\end{tabular}

TABLE 5: Bacteriological characteristics of Kuje abattoir wastewater, source of water used at the abattoir, receiving water bodies upstream and downstream, TC effluents limit for discharge into water bodies and land application in Nigeria (MPN/100 mL).

\begin{tabular}{lcccccc}
\hline Parameter & $\begin{array}{c}\text { Mean value of } \\
\text { abattoir wastewater }\end{array}$ & $\begin{array}{c}\text { Mean value of } \\
\text { water used at } \\
\text { the abattoir }\end{array}$ & $\begin{array}{c}\text { Mean value } \\
\text { of water body } \\
\text { upstream }\end{array}$ & $\begin{array}{c}\text { Mean value } \\
\text { of water body } \\
\text { downstream }\end{array}$ & $\begin{array}{c}\text { *Effluent limit for } \\
\text { discharge into surface } \\
\text { water in Nigeria }\end{array}$ & $\begin{array}{c}\text { *Effluent limit for } \\
\text { discharge into land } \\
\text { application in Nigeria }\end{array}$ \\
\hline TC & $4.4 \times 10^{6}$ & $4.8 \times 10^{3}$ & $5.1 \times 10^{3}$ & $6.0 \times 10^{5}$ & $4.0 \times 10^{2}$ & $5.0 \times 10^{2}$ \\
FC & $4.2 \times 10^{4}$ & $4.0 \times 10^{2}$ & $2.4 \times 10^{3}$ & $2.8 \times 10^{4}$ & - & - \\
F. streptococcus & $2.8 \times 10^{4}$ & $1.8 \times 10^{2}$ & $1.2 \times 10^{3}$ & $1.2 \times 10^{4}$ & - \\
E. coli & $2.4 \times 10^{3}$ & $4.0 \times 10$ & $1.0 \times 10^{2}$ & $1.8 \times 10^{3}$ & - \\
\hline
\end{tabular}


drainages) that are used for drinking, bathing, washing of clothes, home utensils, watering animals, watering of crops, and other domestic purposes downstream at distances of $680 \mathrm{~m}$ at Deidei, $415 \mathrm{~m}$ at Gwagwlada, $610 \mathrm{~m}$ at Karu, $542 \mathrm{~m}$ at kubwa, and $320 \mathrm{~m}$ at kuje area.

Tables 1 to 5 present the mean values of TC, FC, F. streptococcus and E. coli (MPN/100 mL) of the abattoir wastewater, water servicing the abattoirs, water bodies receiving abattoir wastewater at $100 \mathrm{~m}$ upstream and downstream and the recommended TC count of industrial effluents (wastewater) limit for discharge into surface water and land application in Nigeria.

\section{Discussion}

This study was conducted to determine the bacteriological characteristics of abattoir effluents discharged into water bodies and its possible health hazards on receiving water bodies in Abuja, Nigeria. The concentrations of TC, FC, F. streptococcus, and E. coli were determined in the abattoir effluents, water servicing the abattoir, and water bodies receiving abattoir effluents. Bacterial concentrations $(\mathrm{MPN} / 100 \mathrm{~mL})$ of abattoir effluents ranged from $4.8 \times 10^{6}$ to $5.8 \times 10^{5} / 100 \mathrm{~mL}$ of TC, $8.2 \times 10^{4}$ to $3.2 \times 10^{4} / 100 \mathrm{~mL}$ of FC, $5.2 \times 10^{4}$ to $2.0 \times 10^{4} / 100 \mathrm{~mL}$ of $F$. streptococcus, and $1.2 \times 10^{4}$ to $2.0 \times 10^{3} / 100 \mathrm{~mL}$ of $E$. coli while receiving water bodies ranged from $6.2 \times 10^{3}$ to $1.4 \times 10^{3} / 100 \mathrm{~mL}$ of TC, $2.6 \times 10^{3}$ to $2.2 \times 10^{2} / 100 \mathrm{~mL}$ of FC, $1.2 \times 10^{3}$ to $1.2 \times 10^{2} / 100 \mathrm{~mL}$ of F. streptococcus, and $2.0 \times 10^{2}$ to 4.0 $\times 10^{1} / 100 \mathrm{~mL}$ of E. coli $100 \mathrm{~m}$ upstream, and $6.6 \times 10^{5}$ to $6.0 \times 10^{5} / 100 \mathrm{~mL}$ of TC, $6.2 \times 10^{4}$ to $1.8 \times 10^{4} / 100 \mathrm{~mL}$ of FC, $1.8 \times 10^{4}$ to $6.0 \times 10^{3} / 100 \mathrm{~mL}$ of F. streptococcus, and $4.8 \times 10^{3}$ to $6.6 \times 10^{2} / 100 \mathrm{~mL}$ of $E$. coli $100 \mathrm{~m}$ downstream after mixing with the abattoir wastewater. Bacterial counts of $4.8 \times 10^{2}$ to $1.2 \times 10^{2} / 100 \mathrm{~mL}$ of TC, $4.0 \times 10^{2}$ to $2.6 \times 10 / 100 \mathrm{~mL}$ of FC, $1.8 \times 10^{2}$ to $2.1 \times 10 / 100 \mathrm{~mL}$ of F. streptococcus, and $4.8 \times 10$ to $1.2 \times 10 / 100 \mathrm{~mL}$ of E. coli were observed in the water sources servicing the abattoir (Tables 1-5). TC bacteria concentration in the abattoir wastewater discharged exceeded the recommended limit for the discharge of effluents into water bodies and land application in Nigeria [25]. There was no significant difference $(P<0.05)$ between the mean bacterial counts of abattoir wastewater and receiving water bodies $100 \mathrm{~m}$ downstream; is an indication of contamination of receiving water bodies with abattoir wastewater, similar findings has been reported in other places $[2,21,26,27]$. The receiving water bodies were used for drinking, bathing, washing, watering of animals, watering of crops, and other domestic purpose downstream.

Fecal coliforms live in the digestive tract of warmblooded animals; their counts are often used as a surrogate measurement for gastro-enteric pathogens, since the presence of fecal coliform bacteria is an indication of contamination by human and/or animal wastes. E. coli is the most prevalent member of the fecal coliform group; livestock harbour the bacteria and release it in their feces. And so the presence of $E$. coli in water is considered a specific indicator of fecal contamination and the presence of enteric pathogens; it is used as the general indicator organism that signals whether there has been fecal contamination or not. The high levels of total coliforms and E. coli in the abattoir wastewater and receiving water bodies are therefore an indication of the contamination of water sources with feacal material and possibly pathogenic organisms from abattoir wastewater discharged untreated; similar findings have early been reported [2-7]. The discharge of untreated abattoir wastewater could result in out breaks of $E$. coli infection as observed by [28-30]. Bacterial pathogens such as Salmonella [31], Campylobacter, and Listeria monocytogenes [32] have been isolated from abattoir wastewater. The microbial concentrations observed upstream in this study could be as a result of indiscriminate disposal of domestic wastes into water bodies by human beings in these areas.

\section{Conclusion}

This study observed that untreated abattoir wastewater discharged into water bodies in Abuja, Nigeria contains bacterial counts above the recommended level for discharge into water bodies in Nigeria. Receiving water bodies were contaminated with bacteria pathogens that could impact on public health, especially that streams and rivers still serves as major sources of water supply in developing countries like Nigeria. The importance of adopting appropriate abattoir wastewater treatment measures to prevent the chances of contaminating water bodies and ground water in Nigeria is therefore recommended. Determination of specific pathogenic microorganisms in abattoir wastewater and their health impacts is recommended.

\section{References}

[1] C. Obgonnaya, "Analysis of groundwater pollution from abattoir waste in Minna, Nigeria," Research Journal of Dairy Sciences, vol. 2, no. 4, pp. 74-77, 2008.

[2] S. I. B. Cadmus, B. O. Olugasa, and G. A. T. Ogundipe, "The prevalence and zoonotic importance of bovine tuberculosis in Ibadan," in Proceedings of the 37th Annual Congress of the Nigerian Veterinary Medical Association, pp. 65-70, 1999.

[3] J. R. Miner, R. I. Lipper, L. R. Fina, and J. W. Funk, "Cattle feedlot runoff and its nature and variation," Water Pollution Control Federation, vol. 38, p. 1582, 1966.

[4] J. J. Janzen, A. B. Bodine, and L. I. Luszoz, "A survey of effects of animal wastes on streat pollution from selected dairy farms," Journal of Dairy Science, vol. 57, no. 2, pp. 260-263, 1974.

[5] J. W. Doran and D. M. Linn, "Bacteriological quality of runoff water from pastureland," Applied and Environmental Microbiology, vol. 37, no. 5, pp. 985-991, 1979.

[6] J. R. Kunkel, W. M. Murphy, D. Rogers, and D. T. Dugdale, "Seasonal control of gastrointestinal parasites among dairy heifers," Bovine Practitioner, vol. 18, article 54, 1983.

[7] J. Giddens and A. P. Barnett, "Soil loss and microbiological quality of runoff from land treated with poultry litter," Journal of Environmental Quality, vol. 9, no. 3, pp. 518-520, 1980.

[8] T. A. McCaskey, G. H. Robins, and J. A. Little, "Water quality of runoff from grassland applied with liquid, semi liquid and 
dairy day waste," in Livestock Waste Management and Pollution Abatement, pp. 239-243, American Society of Agricultural and Biological Engineers, St. Joseph, Mich, USA, 1971.

[9] E. P. Dunigan and R. P. Dick, "Nutrient and coliform losses in runoff from fertilized and sewage sludge-treated soil," Journal of Environmental Quality, vol. 9, no. 2, pp. 243-250, 1980.

[10] O. Osibanjo and G. U. Adie, "Impact of effluent from Bodija abattoir on the physicochemical parameters of Oshunkaye stream in Ibadan City, Nigeria," African Journal of Biotechnology, vol. 6, no. 15, pp. 1806-1811, 2007.

[11] W. D. Nafarnda, A. Yaji, and H. I. Kubkomawa, "Impact of abattoir waste on aquatic life: a case study of Yola abattoir," Global Journal of Pure and Applied Sciences, vol. 12, pp. 31-33, 2006.

[12] A. O. Coker, B. O. Olugasa, and A. O. Adeyemi, "Abattoir and wastewater quality in South Western Nigeria," in Proceedings of the 27th Water, Engineering and Development Centre Conference, Lusaka, Zambia, 2001.

[13] World Bank, "Poor Management of Processing Wastes. Environmental Assessment: Pressure State Response Indicators," Pollution Prevention and Abatement Handbook, 1998.

[14] B. M. Sherer, R. J. Miner, J. A. Moore, and J. C. Buckhouse, "Indicator bacterial survival in stream sediments," Journal of Environmental Quality, vol. 21, no. 4, pp. 591-595, 1992.

[15] M. D. Sobsey, L. A. Khatib, V. R. Hill, E. Alocilja, and S. Pillai, "Pathogens in Animal Wastes and the Impacts of Waste Management Practices on their Survival, Transport, and Fate," White paper for The National Center for Manure \& Agricultural Waste Management, 2002, http://www.mwpshq.org/.

[16] S. G. Jackson, R. B. Goodbrand, R. P. Johnson et al., "Escherichia coli O157:H7 diarrhoea associated with well water and infected cattle on an Ontario farm," Epidemiology and Infection, vol. 120, no. 1, pp. 17-20, 1998.

[17] L. Armand-Lefevre, R. Ruimy, and A. Andremont, "Clonal comparison of Staphylococcus aureus isolates from healthy pig farmers, human controls, and pigs," Emerging Infectious Diseases, vol. 11, no. 5, pp. 711-714, 2005.

[18] W. F. Schlech, P. M. Lavigne, R. A. Bortolussi et al., "Epidemic listeriosis-evidence for transmission by food," The New England Journal of Medicine, vol. 308, pp. 203-206, 2005.

[19] D. Byamukama, R. L. Mach, F. M. Kansiime, M. Manafi, and A. H. Farnleitner, "Discrimination efficacy of fecal pollution detection in different aquatic habitats of a high-altitude tropical country, using presumptive coliforms, Escherichia coli, and Clostridium perfringens spores," Applied and Environmental Microbiology, vol. 71, no. 1, pp. 65-71, 2005.

[20] United States Environmental Protection Agency (USEPA), "Ambient Water Quality Criteria for Bacteria," EPA 440/5-84002, Washington, DC, USA, 1986.

[21] D. O. Alonge, Textbook of Meat Hygiene in The Tropics, Farmcoe Press, Ibadan, Nigeria, 2nd edition, 2001.

[22] O. Odeyemi, "Consequences of water pollution by solid wastes and feacal materials in Nigeria," in Proceedings of the 3rd National Conference on Water Pollution, pp. 11-17, Port Harcourt, Nigeria, 1980.

[23] CIA Publications, The World Fact Book, 2011.

[24] A. D. Eaton, L. S. Clesceri, E. W. Rice, A. E. Greenberg, and M. A. H. Franson, Standard Methods for the Examination of Water \& Wastewateredition, American Public Health Association, Washington, DC, USA, 21st edition, 2005.

[25] Federal Environmental Protection Agency (FEPA), Guidelines and Standards for Environmental Pollution Control in Nigeria, Ministry of Environment, Lagos, Nigeria, 1991.
[26] N. G. Fransen, A. M. G. Van den Elzen, B. A. P. Urlings, and P. G. H. Bijker, "Pathogenic micro-organisms in slaughterhouse sludge-a survey," International Journal of Food Microbiology, vol. 33, no. 2-3, pp. 245-256, 1996.

[27] M. O. Benka-Coker and O. O. Ojior, "Effect of slaughterhouse wastes on the water quality of Ikpoba River, Nigeria," Bioresource Technology, vol. 52, no. 1, pp. 5-12, 1995.

[28] H. Nelson, "The contamination of organic produce by human pathogens in animal manures," Ecological Agriculture Projects, Faculty of Agricultural and Environmental Science, McGill University (Macdonald Campus), Ste-Annede-Bellevue, QC, Canada, 1997, http://eap.mcgill.ca/SFMC_1 .htm.

[29] P. S. Millard, K. F. Gensheimer, and D. G. Adoiss, "An outbreak of cryptosporidiosis from fresh-pressed apple cider," Journal of the American Medical Association, vol. 272, no. 20, pp. 15921596, 1994.

[30] P. R. Cieslak, T. J. Barrett, and P. M. Griffin, "Escherichia coli 0157:H7 infection from a manured garden," The Lancet, vol. 342, no. 8867, p. 367, 1993.

[31] L. S. Barros, L. A. Amaral, C. S. Lorenzon, J. L. Junior, and J. G. Neto, "Potential microbiological contamination of effluents in poultry and swine abattoirs," Epidemiology and Infection, vol. 135, no. 3, pp. 505-518, 2007.

[32] R. Pepperell, J. Massanet-Nicolau, V. M. Allen, and S. Buncic, "Potential for spread of some bacterial and protozoan pathogens via abattoir wastes applied on agricultural land food protection," Trends, vol. 23, no. 4, pp. 351-325, 2003. 

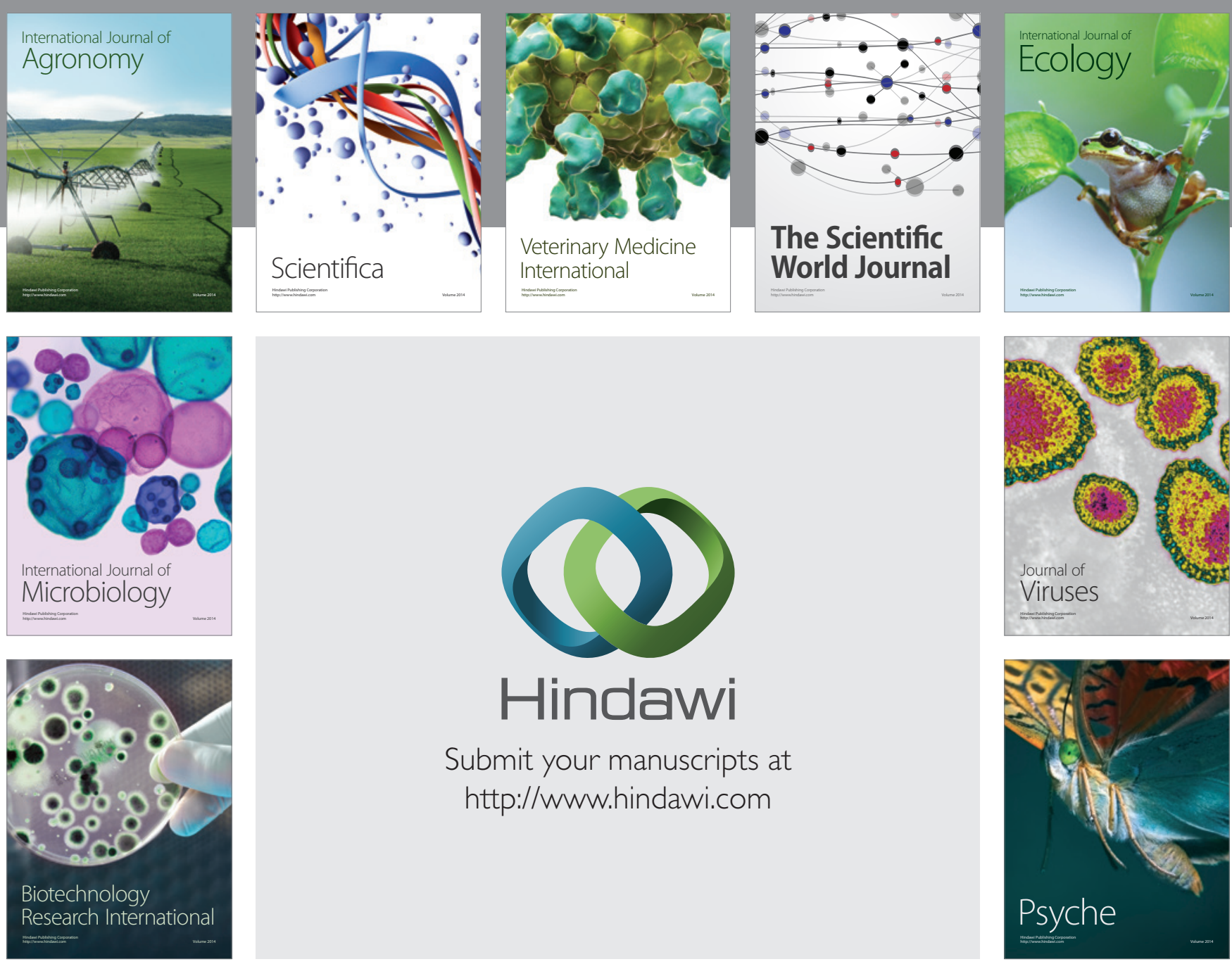

Submit your manuscripts at http://www.hindawi.com
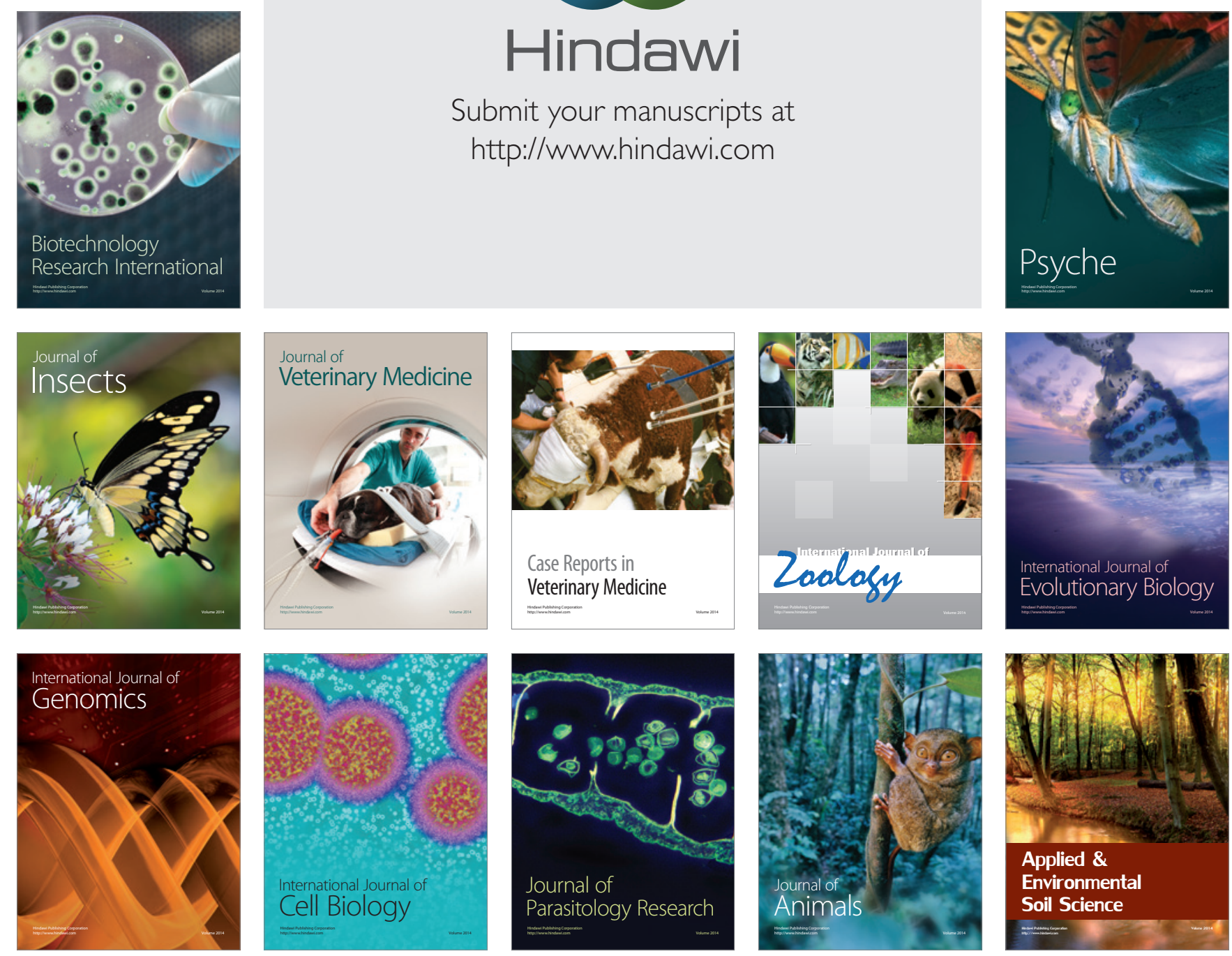